\title{
Appropriate Intravenous Doses of L-Thyroxine and Magnesium in a Thyroidectomized Patient with Thyroid and Parathyroid Carcinomas Receiving Total Parenteral Nutrition During Acute Necrotizing Pancreatitis
}

\author{
Kanji Sato, Shozo Toraya, Keiko Shiratori*, Yoko Kasagi, Yuko Mandai, Toru Miyamoto, \\ Izumi Fukuda, Keizo Kasono, Hiroshi Demura and Takao Obara**
}

\begin{abstract}
A totally thyroidectomized patient with thyroid and parathyroid carcinomas, which had developed after neck irradiation in childhood, became hypercalcemic due to pulmonary metastases. The hypercalcemia was ameliorated by intermittent iv administration of bisphosphonate for 3.5 years, but this gradually became refractory to the bisphosphonate treatment. After right thoracotomy for resection of pulmonary metastases, acute necrotizing pancreatitis developed. The patient was therefore placed on total parenteral nutrition supplemented with $T_{\mathbf{4}}$ and a restricted dose of magnesium. Thyroxine $\left(T_{4}\right)(30 \mu \mathrm{g} / \mathrm{day}$, iv) was not sufficient to maintain euthyroidism, but a higher dose $(60 \mu \mathrm{g} / \mathrm{day})$ elicited mild hyperthyroidism to the same extent as that elicited by an oral dose of $100 \mu \mathrm{g} / \mathrm{day}$. The present case showed that the appropriate iv dose of $T_{4}$ in this thyroidectomized patient with acute pancreatitis was about $60 \%$ of the oral dose. Furthermore, bisphosphonates (pamidronate and alendronate) and magnesium depletion were very effective in controlling the hypercalcemia.
\end{abstract}

(Internal Medicine 34: 176-182, 1995)

Key words: thyroid carcinoma, parathyroid carcinoma, acute necrotizing pancreatitis, bisphosphonate, morphine

\section{Introduction}

The appropriate oral dose of thyroxine $\left(\mathrm{T}_{4}\right)$ for maintaining hypothyroid or athyreotic patients in a euthyroid state is about $1.6-2 \mu \mathrm{g} / \mathrm{kg}$ body weight per day (1-3). However, there are few or no data to indicate adequate iv dose of $\mathrm{T}_{4}$ in totally thyroidectomized patients, particularly when they are critically ill, because serum $T_{3}$ and $T_{4}$ levels are substantially decreased in non-thyroidal illnesses (NTI) (4-6).

Recently, we treated a hypercalcemic patient with parathyroid and thyroid carcinomas, which had developed 40 years after neck irradiation (7-11). The patient underwent total thyroidectomy and was maintained slightly hyperthyroid for 4 years at a daily oral dose of $100 \mu \mathrm{g} \mathrm{T}_{4}$. Despite total resection of the tumors in the neck, hypercalcemia developed due to bilateral lung metastases $(11,12)$. The patient underwent right thoracotomy for resection of the metastases and amelioration of the hypercalcemia (12). After the operation, acute necrotizing pancreatitis developed. Bisphosphonates were repeatedly injected to control the hypercalcemia (13), and the patient was placed on intravenous hyperalimentation (IVH) supplemented with L-thyroxine (30-60 $\mu \mathrm{g} / \mathrm{day})$ to assist the regression of the pancreatitis.

We report here the thyroid function of this totally thyroidectomized patient, who was treated with total parenteral nutrition (TPN) for more than 4 months.

\section{Case Report}

\section{Initial clinical course}

In April 1993, the patient, a 64-year-old woman, was admitted to Tokyo Women's Medical College because of hypercalcemia due to pulmonary metastases of thyroid and parathyroid carcinomas. At the age of 11 years, she underwent irradia-

From the Department of Medicine, ${ }^{*}$ Institute of Gastroenterology, **the Department of Endocrine Surgery, Institute of Clinical Endocrinology, Tokyo Women's Medical College, Tokyo

Received for publication July 13, 1994; Accepted for publication November 7, 1994

Reprint requests should be addressed to Dr. Kanji Sato, the Department of Medicine, Institute of Clinical Endocrinology, Tokyo Women's Medical College, Kawada-cho 8-1, Shinjuku-ku, Tokyo 162 
tion of the neck for treatment of atopic eczema (11). In 1981 (age 53), she noticed thyroid nodules, and left thyroid lobectomy was performed. The pathological diagnosis was papillary carcinoma of the thyroid $(7,11)$. In 1984, hypercalcemia developed, and a parathyroid tumor was resected. The diagnosis was parathyroid carcinoma (11). Hypercalcemia persisted, and extracorporeal shock-wave lithotripsy failed to remove renal stones in the left kidney, resulting in left hydronephrosis. In 1988, the thyroid tumor recurred in the neck. Complete thyroidectomy was performed and the tumors, which were found to have invaded into the esophagus and trachea (papillary carcinoma), were removed. She was administered $\mathrm{T}_{4}$ at an oral dose of $125-150 \mu \mathrm{g} /$ day to minimize thyroid stimulating hormone (TSH)-dependent tumor growth. The dose was reduced to $100 \mu \mathrm{g} /$ day to maintain thyroid function in a slightly hyperthyroid state $(14,15)$ (Table 1$)$. The serum calcium concentration gradually increased and exceeded $14 \mathrm{mg} / \mathrm{dl}$ in September 1989, accompanied by increased urinary excretion of calcium (300-490 mg/day). From November 1989, pamidronate (45-60 mg. Ciba Geigy, Osaka) was intermittently administered iv to decrease the serum calcium concentration to below $13-14 \mathrm{mg} / \mathrm{dl}$ (13). In the early period of administration, this was very effective for ameliorating the hypercalcemia, but after the 20th administration, the hypercalcemia became refractory to bisphosphonate (Fig. 1). In April 1993, it was not possible to decrease the serum calcium concentration to below $15 \mathrm{mg} / \mathrm{dl}$, despite iv injection every 4 th week. Plasma intact parathyroid hormone (PTH) increased steadily to 2,602 $\mathrm{pg} / \mathrm{ml}$, accompanied by a marked increase in serum alkaline phosphatase activity (3,341 IU/L). Muscle weakness, and pain in the knee joints due to pseudogout worsened, making it difficult for the patient to visit the hospital on foot.

\section{Clinical course in the Department of Surgery}

On admission, the patient weighed $37 \mathrm{~kg}$, and her height was $156 \mathrm{~cm}$. She complained of general fatigue and nocturia, but was mentally alert with good intellect. The serum calcium concentration was $15.7 \mathrm{mg} / \mathrm{dl}, \mathrm{P} 1.9 \mathrm{mg} / \mathrm{dl}$. Mg $0.9 \mathrm{mEq} / \mathrm{L}$, albumin $3.8 \mathrm{~g} / \mathrm{dl}$, Blood urea nitrogen $(\mathrm{BUN}) 21.9 \mathrm{mg} / \mathrm{dl}$, creatinine $1.0 \mathrm{mg} / \mathrm{dl}, \mathrm{Na} 141 \mathrm{mEq} / \mathrm{L}, \mathrm{K} 3.8 \mathrm{mEq} / \mathrm{L}, \mathrm{Cl} 111 \mathrm{mEq} /$ L. CT scan revealed multiple metastases in the bilateral pulmonary field (Fig. 2). On May 19, right thoracotomy was performed as part of a staged bilateral thoracotomy (12), and 57 small metastatic tumors (approximately $7 \mathrm{~g}$ in total) were resected. The pathological diagnosis was thyroid carcinoma ( 15 of the 57 tumors, chiefly the larger nodules) and parathyroid carcinoma (42 of the 57 tumors, the smaller nodules). Eight days after the operation, severe abdominal pain developed, and serum amylase increased to 2,951 U/L. Under a diagnosis of acute pancreatitis, nafamostat mesilate (Futhan, $20 \mathrm{mg}$ ) was administered iv. The patient was maintained by IVH (total $1,400 \mathrm{cal})$, depleted of phosphate and magnesium.

Table 1. Thyroid Function of the Patient

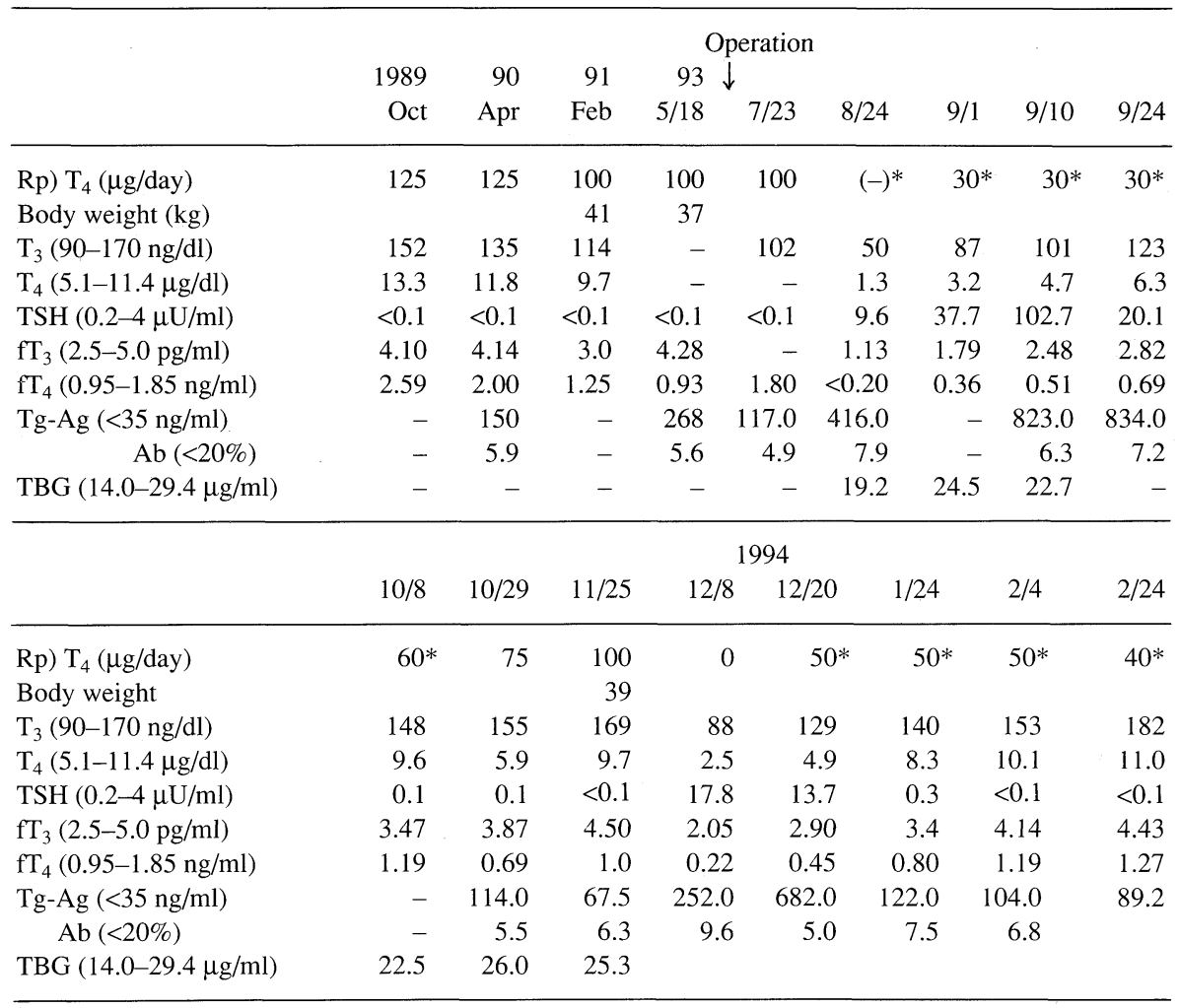

*indicates that $\mathrm{T}_{4}$ was administered iv. TBG: thyroxine-binding globulin. 


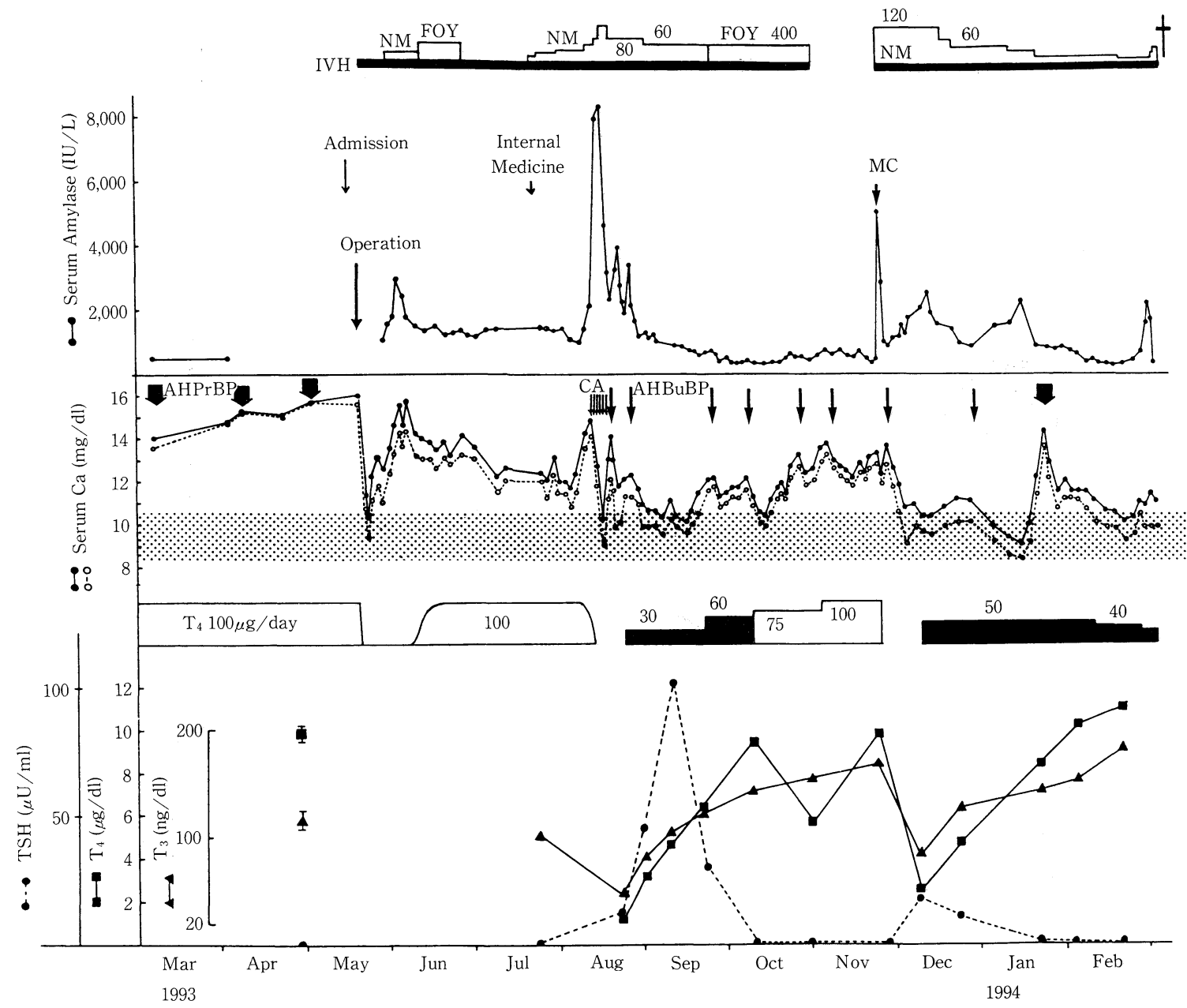

Fig. 1. Clinical course of the patient.

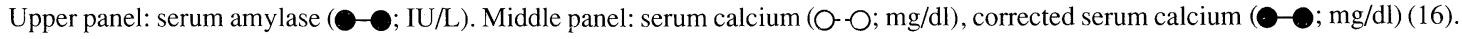

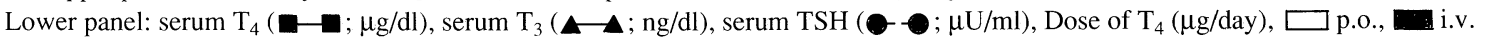

NM: nafamostat mesilate, MC: morphine chloride (10 mg), CA: elcatonin $80 \mathrm{lU} /$ day (im), AHPrBP: pamidronate $60 \mathrm{mg}$ (iv), AHBuBP: alendronate $10 \mathrm{mg}$ (iv). Dotted areas indicate a normal range of serum calcium.

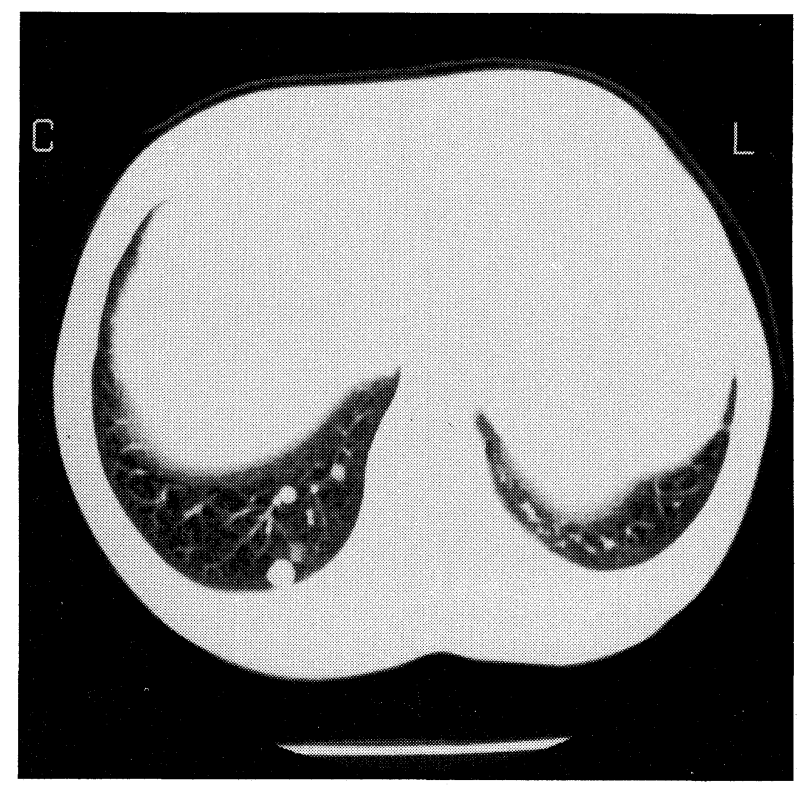

\section{Clinical course in the Department of Medicine}

On July 23, she was transferred to the Department of Medicine, for control of hypercalcemia and pancreatitis. The serum calcium concentration was $11.4 \mathrm{mg} / \mathrm{dl}$, and albumin 3.6 $\mathrm{g} / \mathrm{dl}$. The corrected serum calcium concentration was $11.8 \mathrm{mg} /$ $\mathrm{dl}$ (16). On July 30, the patient collapsed due to a syncopal attack, and became stuporous and disoriented. Under a diagnosis of metabolic encephalopathy due to hypophosphatemia (P: $0.4 \mathrm{mg} / \mathrm{dl})$ and hypomagnesemia $(\mathrm{Mg}: 0.2 \mathrm{mEq} / \mathrm{L})(17,18)$, IVH was supplemented with Paremental B containing phosphate $(12 \mathrm{mmol})$ and $\mathrm{Mg}(4.5 \mathrm{mMq})$. The serum $\mathrm{Mg}$ concentration increased gradually to $1.6 \mathrm{mEq} / \mathrm{L}$ on August 9 . Subsequently, the serum calcium concentration increased rapidly to $14.1 \mathrm{mg} / \mathrm{dl}$. Severe abdominal pain developed, accompanied by ascites and pleural effusion. The serum amylase level increased

Fig. 2. CT scan of the chest. Multiple nodular lesions are present in the bilateral lung bases. 
to $8,490 \mathrm{IU} / \mathrm{L}$. Leukocytosis $\left(23,000 / \mathrm{mm}^{3}\right)$, hypoproteinemia $(4.8 \mathrm{~g} / \mathrm{dl})$ and hypoalbuminemia $(2.2 \mathrm{~g} / \mathrm{dl})$ developed (19). Abdominal CT scan revealed ascites and a pseudocyst in the enlarged pancreas (Fig. 3). The intravenous dose of nafamostat mesilate was increased to $80-120 \mathrm{mg}$. The level of amylase in the ascites was $181,575 \mathrm{IU} / \mathrm{L}$. Following intraperitoneal administration of nafamostat mesilate $(50 \mathrm{mg}$ ) on August 19, the ascites was markedly decreased. Calcitonin (elcatonin, $40 \mathrm{U}$ twice daily, im) was administered, and this was followed by a marked decrease in the serum calcium concentration, which could have been partly due to the severe pancreatitis per se (20). However, escape phenomenon developed on day 6, and alendronate $(10 \mathrm{mg})$ was administered iv, resulting in very effective control of the hypercalcemia (21). To ameliorate the pancreatitis induced by the hypercalcemia, alendronate (Teijin Pharmaceutical Co., Tokyo) was repeatedly administered. To assist the regression of acute pancreatitis, the patient was placed on a nothing-by-mouth regimen, and after obtaining informed consent, $\mathrm{T}_{4}$ was added to IVH containing $1,600 \mathrm{kcal}$. To ameliorate the PTH-induced hypercalcemia, administration of magnesium was restricted to about $1 \mathrm{mEq} / \mathrm{day}$, so that moderate hypomagnesemia persisted. The serum amylase level gradually decreased to less than $500 \mathrm{U} / \mathrm{L}$ in October, and the IVH was tapered off.

On November 2, IVH was discontinued and the patient was allowed to eat a low fat, low-calcium diet. $\mathrm{T}_{4}$ was taken orally from October 12 at a dose of $75 \mu \mathrm{g} / \mathrm{day}$, which was increased to $100 \mu \mathrm{g} /$ day on November 3 . She started muscle training again in the rehabilitation department, but complained of muscle and knee joint pain during walking. Non-steroidal anti-inflammatory drugs were prescribed, which caused abdominal pain and gastrointestinal bleeding.

To promote the rehabilitation program, a morphine chloride suppository (10 mg, Ampeck) was prescribed on November 26. A few hours after rectal insertion, the patient complained of abdominal discomfort, and the serum amylase level increased to $5,190 \mathrm{U} / \mathrm{L}$. Oral intake was stopped and IVH was again

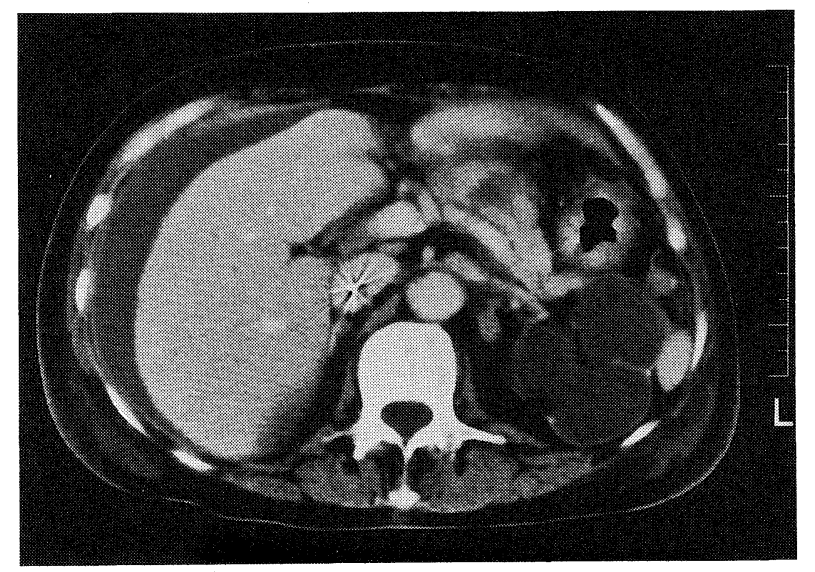

Fig. 3. CT scan of the abdomen. CT scan on August 22, 1993 reveals ascites and an enlarged pancreas with formation of a pseudocyst. The left kidney is hydronephrotic. started. Although the acute pancreatitis rapidly subsided, the patient did not do well. Serum alkaline phosphatase activity, the major proportion being of bone origin, exceeded 4,500 IU/L. On March 1, she fell onto the floor, resulting in bilateral femoral fracture at the diaphysis. Anemia and metabolic acidosis worsened. Pneumonia developed and the patient died of respiratory failure on March 7. Autopsy was not performed. The total doses of pamidronate and alendronate administered during the course were $1,305 \mathrm{mg}$ (23 times) and $81.25 \mathrm{mg}$ ( 9 times), respectively.

\section{Intravenous dose of L-thyroxine}

L-thyroxine (Sigma Chemical Co., St. Louis, MO, USA) was dissolved in $0.1 \mathrm{~N} \mathrm{NaOH}$ and sterilized by filtering through a millipore membrane in the pharmaceutical division of the hospital. One vial contained $50 \mu \mathrm{g} \mathrm{T}_{4}$ in $2 \mathrm{ml}$ of solution $(\mathrm{pH}$ 10.0). While the patient was receiving TPN, $\mathrm{T}_{4}$ was administered from a lateral tube by bolus injection.

\section{Measurement of serum $T_{3}, T_{4}, T S H$ and selenium concentration}

To minimize the effect of blood sampling time on thyroid hormone concentration, all samples were taken at 9-10 AM in the outpatient clinic and at 5-6 AM during the admission (22). Serum levels of $T_{4}$, free $T_{4}$ and free $T_{3}$ were determined using commercial kits (Amerlex-M T 4 , Amerlex-M free $\mathrm{T}_{4}$, Amerlex $\mathrm{M}$-free $\mathrm{T}_{3}$; Nihon-Kodak, Tokyo). $\mathrm{T}_{3}$ and thyroglobulin were determined using RIA kits (Eiken-Kagaku, Tokyo). TSH and intact PTH were determined by immunoradiometric assays (Diagnost-TSH; Hekisuto Japan, Immuno PTH-intact; Baxter, Tokyo). Serum selenium concentration was determined by atomic absorption spectroscopy (Mitsubishi Yuka BCL, To-

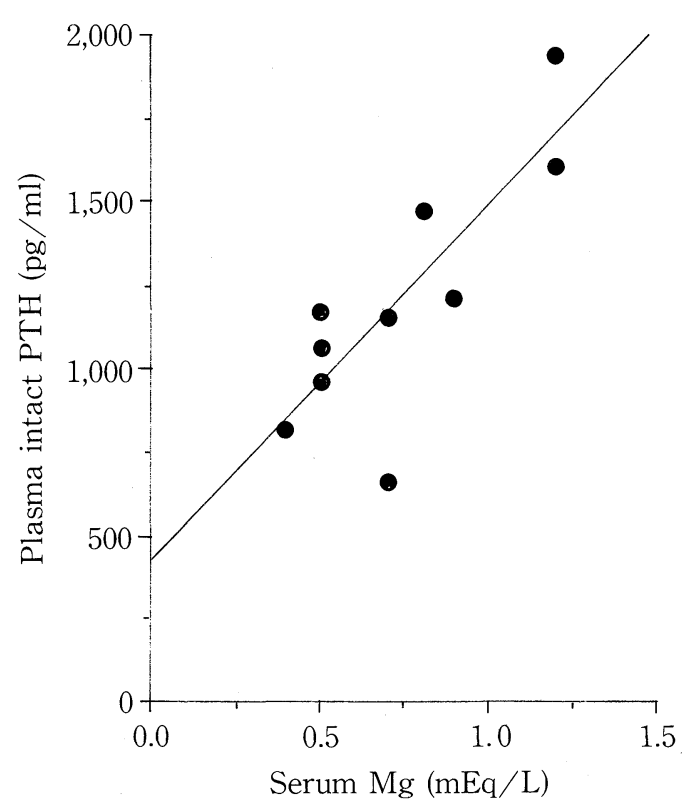

Fig. 4. Correlation between serum levels of intact PTH and $\mathrm{Mg}$. There was a significant correlation between plasma intact PTH concentration $(\mathrm{pg} / \mathrm{ml})$ and serum $\mathrm{Mg}$ concentration $(\mathrm{mEq} / \mathrm{L})$ in samples taken after surgery. $\mathrm{Y}=1069 \mathrm{X}+419.7, \mathrm{r}=0.653$, $\mathrm{P}<0.05(\mathrm{n}=10)$. 


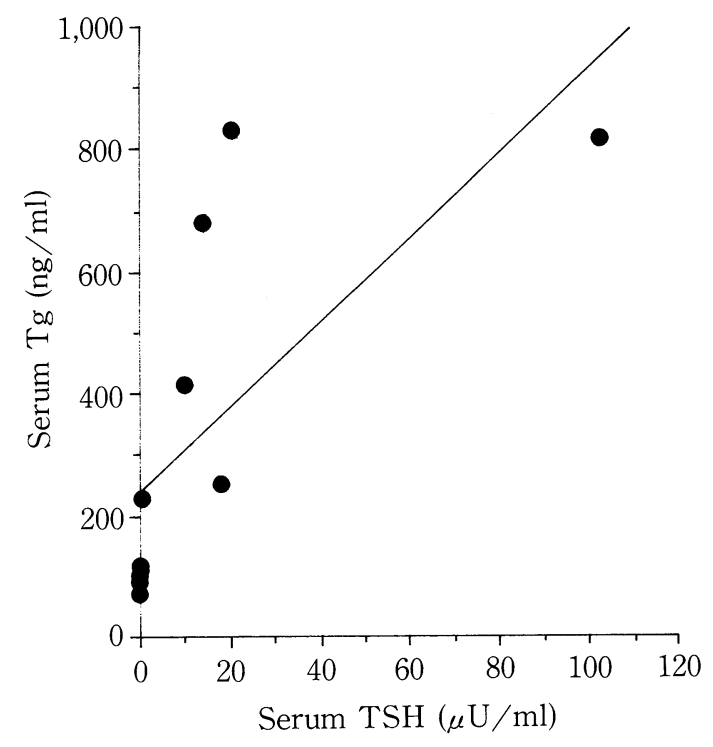

Fig. 5. Correlation between serum levels of TSH and thyroglobulin. There was a significant correlation between serum TSH and thyroglobulin concentration in samples taken after surgery. $\mathrm{Y}=6.98 \mathrm{X}+234.7, \mathrm{r}=0.484, \mathrm{P}<0.05(\mathrm{n}=11)$.

kyo).

Thyroid function during IVH is summarized in Table 1 . There was a significant correlation between the serum levels of $\mathrm{Mg}$ and intact PTH after the operation (Fig. 4). Furthermore, a significant correlation was also found between the serum levels of TSH and thyroglobulin (Fig. 5).

\section{Discussion}

Since the average absorption rate of $\mathrm{T}_{4}$ in normal subjects is approximately $80 \%(23,24)$, the dose of $\mathrm{T}_{4}$ for iv injection should be about $20 \%$ less than that taken by mouth (1). This was proved to be the case, at a rough estimate, in the present athyreotic patient, who was placed on TPN for more than 4 months because of relapsing acute pancreatitis following thoracic surgery.

When patients with low serum $T_{4}$ and $T_{3}$ concentrations recover from NTI, the level of TSH first increases, followed by a gradual increase in serum $\mathrm{T}_{4}$ concentration and a subsequent increase of $\mathrm{T}_{3}(25,26)$. On the assumption that $\mathrm{T}_{4}$ treatment of the euthyroid sick state of NTI patients is not beneficial, and may impair an important beneficial adaptation to illness in man (4), we started $\mathrm{T}_{4}$ infusion at a low dose of $30 \mu \mathrm{g} /$ day. $\mathrm{T}_{4}$ was converted effectively to $T_{3}$, resulting in an increased ratio of $\mathrm{T}_{3} /$ $\mathrm{T}_{4}$, a good predictor for survival (25). Despite steadily increasing levels of $\mathrm{T}_{3}$ and $\mathrm{T}_{4}, \mathrm{TSH}$ increased transiently to $100 \mu \mathrm{U} / \mathrm{ml}$, suggesting that the underlying illness was in the recovery phase (25). However, daily infusion of $30 \mu \mathrm{g} \mathrm{T}_{4}$ for 30 days was not sufficient to maintain the patient in a euthyroid state (TSH $<4$ $\mu \mathrm{U} / \mathrm{ml})$. Therefore, the dose of $\mathrm{T}_{4}$ was doubled for an additional 18 days, resulting in suppression of TSH $(<0.1 \mu \mathrm{U} / \mathrm{ml})$. Since 4 to 6 weeks is generally required for the daily dose of $T_{4}$ to reach equilibration in human subjects (1), these clinical data suggest that the adequate iv dose for maintaining euthyroidism in this patient (weighing $39 \mathrm{~kg}$ ) was more than 30 but less than $60 \mu \mathrm{g} /$ day during the convalescent phase.

On the assumption that the appropriate dose of $\mathrm{T}_{4}$ was $50 \mu \mathrm{g}$ per day and that $80 \%$ would be absorbed $(23,24), \mathrm{T}_{4}(75 \mu \mathrm{g})$ was given orally. However, the serum $\mathrm{T}_{4}$ level decreased to 5.9 $\mu \mathrm{g} / \mathrm{dl}$, and thereafter, the dose of $\mathrm{T}_{4}$ was increased to $100 \mu \mathrm{g} /$ day, resulting in a slightly hyperthyroid state $\left(\mathrm{T}_{4} 9.7 \mu \mathrm{g} / \mathrm{dl}\right.$, TSH $<0.1 \mu \mathrm{U} / \mathrm{ml}$ ). Since the serum $\mathrm{T}_{4}$ level at this dose was very close to that while the patient was receiving an iv dose of $60 \mu \mathrm{g} /$ day $\left(\mathrm{T}_{4} 9.6 \mu \mathrm{g} / \mathrm{dl}, \mathrm{TSH}<0.1 \mu \mathrm{U} / \mathrm{ml}\right)$, we estimated that about $60 \%$ of oral $\mathrm{T}_{4}$ was absorbed in the present patient, which is in good accordance with the estimate reported by Hays and Nielsen in patients with pancreatic diseases $(23,24)$.

After the second relapse of acute pancreatitis, the patient was placed on TPN again. $\mathrm{T}_{4}$ was not employed for the first 14 days, resulting in a decrease of serum $\mathrm{T}_{4}$ from $9.7 \mu \mathrm{g} / \mathrm{dl}$ to $2.5 \mu \mathrm{g} / \mathrm{dl}$, the $T_{4}$ level expected on the basis of the half-time of $T_{4}$ in serum (6-7 days). It should be stressed that such a decreased $\mathrm{T}_{4}$ level can be frequently observed in patients with NTI, suggesting that thyroid hormone secretion is markedly decreased or its catabolism is markedly erihanced in critically ill states (4). From December $8, \mathrm{~T}_{4}$ was infused constantly at a daily dose of $50 \mu \mathrm{g} /$ day. Serum $\mathrm{T}_{4}$ increased gradually to $10 \mu \mathrm{g} / \mathrm{dl}$, suggesting that the patient's requirement for, or consumption of $T_{4}$ was decreasing. The $T_{4}$ dose was decreased to $30 \mu \mathrm{g} /$ day after the femur fracture, and discontinued at the terminal stage. At the present time, we still do not know the optimum dose of $T_{4}$ for patients in such a critically ill state.

Type I iodothyronine-5'-deiodinase, a selenocysteine-containing enzyme (28), plays a key role in converting $\mathrm{T}_{4}$ to $\mathrm{T}_{3}$, and selenium deficiency is known to be responsible for low $\mathrm{T}_{3}$ and high $\mathrm{T}_{4}$ levels in experimental animals (28). Although the serum selenium concentration in the present patient was slightly decreased, a low $T_{3}$ state was not seen (Table 2), reflecting the fact that a period of more than one year is required before selenium deficiency occurs in human subjects (29). The serum $\mathrm{T}_{3} / \mathrm{T}_{4}$ ratio was rather increased during IVH compared to that when the patient was attending the outpatient clinic, suggesting that she was well-nourished by the IVH. Indeed, her body weight at this time was increasing (Table 1). It is well known that overfeeding and a carbohydrate-rich diet increases the $\mathrm{T}_{3} /$ $\mathrm{T}_{4}$ ratio (30), which is due at least partly to increased secretion of insulin, a potent stimulator of iodothyronine-5' -deiodinase (31).

Table 2. Serum Selenium Concentration and Thyroid Function

\begin{tabular}{lccc}
\hline & August '91 & January '94 & February '94 \\
\hline Serum $\mathrm{T}_{3}(\mathrm{ng} / \mathrm{dl})$ & 170 & 140 & 182 \\
Serum $_{4}(\mu \mathrm{g} / \mathrm{dl})$ & 15.0 & 8.3 & 11.0 \\
Serum $\mathrm{rT}_{3}(\mathrm{ng} / \mathrm{dl})$ & 54 & 23 & 73 \\
$\mathrm{~T}_{3} / \mathrm{T}_{4}$ ratio & 11.3 & 12.0 & 16.5 \\
Serum selenium $(\mu \mathrm{g} / \mathrm{dl})$ & 18.6 & 13.4 & 10.9 \\
\hline
\end{tabular}


It should be pointed out that acute pancreatitis, which developed postsurgically, became exacerbated twice after the patient was transferred to the Department of Medicine: once accompanied by an increase in the serum calcium concentration after correction of hypomagnesemia, and immediately after the insertion of a morphine chloride suppository.

In subjects with normal parathyroid glands, chronic hypomagnesemia causes hypocalcemia by impairing the secretion of PTH and its action on target organs (17). After the patient developed metabolic encephalopathy due to hypomagnesemia and hypophosphatemia $(17,18)$ IVH was supplemented with Paremental B containing $12 \mathrm{mmol} \mathrm{P}$ and $4.5 \mathrm{mEq} \mathrm{Mg}$. Correction of the hypomagnesemia rapidly increased the serum calcium concentration (32), leading to acute exacerbation of necrotizing pancreatitis (Fig. 3). Although the level of plasma intact PTH was not determined at the time of hypercalcemic crisis, correction of hypomagnesemia is reported to stimulate PTH secretion (17), and in fact, a significant correlation was found between the levels of serum $\mathrm{Mg}$ and intact PTH after thoracotomy (Fig. 4). To impair PTH secretion, Mg was depleted again from IVH until the serum $\mathrm{Mg}$ level had decreased to $0.5 \mathrm{mEq} / \mathrm{L}$. Thereafter, $\mathrm{Mg}$ was infused at a dose equivalent to the level excreted into urine the day before (usually $<1 \mathrm{mEq} /$ day). Therefore, we suggest that the following IVH regimen was most suitable for this patient with parathyroid carcinoma: glucose and amino acids, $0.5 \mathrm{M} \mathrm{K}_{2} \mathrm{HPO}_{4}(20-30 \mathrm{ml}), 7.5 \%$ $\mathrm{NaHCO}_{3}$ (Meiron, 60-100 ml), $\mathrm{MgCl}_{2}$ (Magnesol, $1 \mathrm{mEq}(1$ $\mathrm{ml}$ ), and multi-vitamins depleted of vitamin $\mathrm{D}$ (total volume, 3,000-3,500 ml, total calorie; $1,400 \mathrm{kcal}$ content, urinary $\mathrm{Na}$ excretion $200-300 \mathrm{mEq} /$ day). With this calcium-free IVH regimen, urinary calcium excretion was decreased to $30-60$ $\mathrm{mg} /$ day.

Needless to say, morphine chloride is contraindicated for patients with acute pancreatitis (33). This was also the case in the recovery, even though it was administered as a suppository. Since no such warning is described in the specifications for the suppository, caution should be exercised in its use. As an analgesic in the present case, buprenorphine hydrochloride (Repetan) was most efficacious for control of pain without any adverse effect on pancreatic function.

Finally, it should be pointed out that the bisphosphonates, pamidronate and alendronate, were very effective for control of hypercalcemia in this patient for a prolonged period $(21,34$, 35 ). There was no adverse effect during or after iv administration, and the patient was able to maintain a good quality of life for at least 3 years, with intermittent injections of pamidronate at the outpatient clinic. These agents will be widely applicable for patients with parathyroid carcinoma as well as parathyroid adenoma, which for any reason have not been completely resected. Although bone fracture occurred 7 days before death, this would have been unrelated to the prolonged administration of both bisphosphonates. The patient had been receiving IVH depleted of calcium, magnesium and vitamin $\mathrm{D}$ for more than 8 months (Fig. 1), and the marked increase in serum alkaline phosphatase activity of bone origin suggested osteomalacia. In addition, a decreased bone mineral content in the cortical bone of long bones with a relatively normal BMD in the trabecular bone of the vertebrae is a salient clinical feature of primary hyperparathyroidism (36).

In summary, the appropriate iv dose of $\mathrm{T}_{4}$ in this totally thyroidectomized patient was approximately $60 \%$ of the oral dose during the convalescent phase of acute necrotizing pancreatitis. However, the dose was decreased when the general condition deteriorated. Second, correction of hypomagnesemia increased the serum calcium concentration in patients with primary hyperparathyroidism, and may have aggravated acute pancreatitis. Therefore, IVH was supplemented with a restricted dose of magnesium to ameliorate the PTH-induced hypercalcemia. Third, a morphine chloride suppository was contraindicated in this patient with acute pancreatitis even though it was absorbed gradually. Fourth, intermittent administration of bisphosphonate (pamidronate and alendronate) was very effective for ameliorating the hypercalcemia for a prolonged period (3.5 years).

Acknowledgments: The authors thank Ciba Geigy (Basel, Switzerland) and Teijin Pharmaceutical Co. (Tokyo, Japan) for providing pamidronate and alendronate, respectively.

\section{References}

1) Surks MI. Treatment of Hypothyroidism. in: Werner and Ingbar's The Thyroid: A Fundamental and Clinical Text. 6th Ed. Braverman LE, Utiger RD, Ed. Lippincott Co., Philadelphia, 1991, p.1099.

2) Fish LH, SchwartzHl, Cavanaugh J, Steffes MW, Bantle JP, Oppenheimer $\mathrm{JH}$. Replacement dose, metabolism, and bioavailability of levothyroxine in the treatment of hypothyroidism. N Engl J Med 316: 764, 1987.

3) Maeda M, Kuzuya N, Masuyama $Y$, et al. Changes in serum triiodothyronine, thyroxine, and thyrotropin during treatment with thyroxine in severe primary hypothyroidism. J Clin Endocrinol Metab 43: 10, 1976.

4) Docter R, Krenning EP, de Jong M, Hennemann G. The sick euthyroid syndrome: changes in thyroid hormone serum parameters and hormone metabolism. Clin Endocrinol 39: 499, 1993.

5) Kaptein EM. Thyroid hormone metabolism in illness. in: Thyroid Hormone Metabolism. Hennemann G, Eds. Marcel Dekker, Inc., New York, 1986, p.297.

6) Nicoloff JT, LoPresiti JS. Thyroid function in nonthyroidal disease. in: Werner and Ingbar's The Thyroid: A Fundamental and Clinical Text. 6th Ed. Braverman LE, Utiger RD, Ed. Lippincott Co., Philadelphia, 1991, p.357.

7) Schneider AB, Shore-Freedman E, Ryo UY, Bekerman C, Favus M, Pinsky S. Radiation-induced tumors of the head and neck following childhood irradiation: prospective studies. Medicine 64: 1, 1985.

8) Robbins J, Merino MJ, Boice JD Jr, et al. Thyroid cancer: a lethal endocrine neoplasm. Ann Intern Med 115: 133, 1991.

9) Rosen IB, Strawbridge HG, Bain J. A case of hyperparathyroidism associated with radiation to head and neck area. Cancer 36: 1111, 1974.

10) Tisell LE, Carlsson $S$, Fjälling $M$, et al. Hyperparathyroidism subsequent to neck irradiation. Cancer 56: 1529, 1985.

11) Fujimoto $Y$, Obara $T$, Fukuuchi A, Tanaka R, Takahashi $Y$, Takemura $T$. Thyroid and parathyroid carcinomas after neck irradiation. Endocrine Surgery (Naibunpi Geka) 7: 443, 1990.

12) Obara $T$, Okamoto $T$, Ito $Y$, et al. Surgical and medical management of patients with pulmonary metastasis from parathyroid carcinoma. Surgery 114: 1040,1993

13) Fleisch H. Bisphosphonates in bone diseases. From Laboratory to the Patients. Stämpfli Co. Ltd., Graphic Enterprise, Berne, Switzerland, 1993. 


\section{SATo et al}

14) Diamond T, Nery L, Hales I. A therapeutic dilemma: Suppressive doses of thyroxine significantly reduce bone mineral measurements in both premenopausal and postmenopausal women with thyroid carcinoma. $\mathrm{J}$ Clin Endocrinol Metab 72: 1184, 1991.

15) Roti E, Minelli R, Gardini E, Braverman LE. The use and misuse of thyroid hormone. Endocr Rev 14: 401, 1993.

16) Payne RB, Little AJ, Williams RB, Milner JR. Interpretation of serum calcium in patients with abnormal serum proteins. Br Med J 111: 643, 1973.

17) Alfrey AC. Disorders of magnesium metabolism. in: The Kidney, Physiology and Pathophysiology. Second edition, Seldin DW, Giebisch G, Eds. Raven Press, Ltd., New York, 1992, p.2357.

18) Knochel JP. The clinical and physiological implications of phosphate deficiency. in: The Kidney, Physiology and Pathophysiology. Second edition, Seldin DW, Giebisch G, Eds. Raven Press, Ltd., New York, p.2533, 1992.

19) Steinberg W, Tenner S. Acute pancreatitis. N Engl J Med 330: 1198, 1994.

20) Stewart AF. Hypocalcemia due to pancreatitis. in: Primer on the Metabolic Bone Diseases and Disorders of Mineral Metabolism. Favus MJ, Ed. Second Ed. Raven Press, New York, 1993, p.202.

21) Sato K, Hattori $T$, Tomita A, et al. Comparative clinical study of alendronate with eel calcitonin in hypercalcemia of malignancy. RinshouIyaku 10: 2667, 1994 (in Japanese).

22) Ain KB, Pucino F, Shiver TM, Banks SM. Thyroid hormone levels affected by time of blood sampling in thyroxine-treated patients. Thyroid 3: 81, 1993.

23) Hays MT. Thyroid hormone and the gut. Endocrine Rev 14: 203, 1988.

24) Hays MT, Nielsen KRK. Human thyroxine absorption: age effects and methodological analyses. Thyroid 4: 55, 1994.

25) Brent GA, Hershman JM. Thyroxine therapy in patients with severe nonthyroidal illnesses and low serum thyroxine concentration. J Clin
Endocrinol Metab 63: 1, 1986.

26) Wehmann RE, Gregerman RI, Burns WH, Saral R, Santos GW. Suppression of thyrotropin in the low-thyroxine state of severe non-thyroidal illness. N Engl J Med 312: 546, 1985.

27) Berry MJ, Banu L, Larsen PR. Type I iodothyronine deiodinase is a selenocysteine-containing enzyme. Nature 349: 438, 1991.

28) Berry MJ, Leed PR. The molecular cloning of type I iodothyronine deiodinase: new insights into thyroid hormone action. Thyroid Today 14: $1,1991$.

29) Clouse RE. Parenteral nutrition. "Cecil" Textbook of Medicine, 18th edition, Wyngaarden JB, Smith LH, Eds. Saunders Co., Philadelphia, 1988, p.1247.

30) Danforth E Jr. Effects of fasting and altered nutrition on thyroid hormone metabolism in man. in: Thyroid Hormone Metabolism. Hennemann G, Ed. Marcel Dekker, Inc., New York, 1986, p.335.

31) Sato K, Robbins J. Thyroid hormone metabolism in primary cultured rat hepatocytes. Effects of glucose, glucagon, and insulin. J Clin Invest 68: 475, 1981.

32) Rude RK, Oldham SB, Singer DB. Functional hypoparathyroidism and parathyroid hormone end-organ resistance in human magnesium deficiency. Clin Endocrinol 5: 209, 1976.

33) Jaffe JH, Martin WR. Opioid analgesics and antagonists. in: The Pharmacological Basis of Therapeutics. Eighth edition. Gilman AG, Rall TW, Nies AS, Taylor P, Eds. Pergamon Press, New York, 1990, p.485.

34) Bilezikian JP. Management of acute hypercalcemia. N Engl J Med 326: 1196, 1992.

35) Nussbaum SR, Younger J, VandePol CJ, et al. Single-dose intravenous therapy with pamidronate for the treatment of hypercalcemia of malignancy: comparison of 30-, 60-, and 90-mg dosages. Am J Med 95: 297, 1993.

36) Silverberg SJ, Shane E, de la Cruz L, et al. Skeletai disease in primary hyperparathyroidism. J Bone Min Res 4: 283, 1989. 